\title{
Research on the Establishment and Evaluation of Operational Risk Model of Current Financial İnstitutions in China
}

\author{
Jingwei Lyu ${ }^{1}$ \\ ${ }^{1}$ College of Finance, Shanghai University of Finance and Economics, Shanghai, China \\ Correspondence: Jingwei Lyu, College of Finance, Shanghai University of Finance and Economics, Shanghai, \\ China.
}

Received: December 2, 2015

Accepted: December 18, $2015 \quad$ Online Published: January 4, 2016

doi:10.5430/ijba.v7n1p20

URL: http://dx.doi.org/10.5430/ijba.v7n1p20

\begin{abstract}
Along with the development of economic globalization, all countries have got the development of the huge interest, and the economy has made rapid progress as well. But at the same time, they are also under huge financial risk, what's more, the financial crisis has occurred from time to time. The assessment of the risk of financial institutions is one of the important ways to predict and deal with the financial crisis. This paper summarizes the current financial risk assessment system, then puts forward the ideas and methods of the establishment of financial institutions risk model, analyzes the internal and external financial risks, and to study its function. Finally, this paper puts forward two important measures of market oriented and government intervention to deal with financial risks.
\end{abstract}

Keywords: economic globalization, financial risk, risk assessment, government intervention

\section{Introduction}

Over the past few decades, the maintenance of financial stability and prevention of systemic financial risk has become the major concern of governments, financial regulators. And in 2007 the international financial turmoil sweeping the world, the country is more concerned about the stability of the financial system and its impact on the real economy. In July 2010, the U.S. Congress passed the most comprehensive financial reform act of 1930s - the Frank Dodd act, and the establishment of a Financial Stability Oversight Committee (FSOC), responsible for monitoring and dealing with the threat of financial stability of the country's systemic risk. The EU has also established a system of the European systemic risk Council (ESRB) to prevent the occurrence of systemic financial risks and maintain the financial stability of its member states. The recent international financial crisis has caused the supervision department, the academic circles to the past with the individual financial risk as the core of the micro prudential supervision way. And the financial system as a whole of the macro prudential supervision of the regulatory approach to the crisis in the reserve.

The impact of the financial crisis in Southeast Asia on the credit quality of the Southeast Asian countries and the strengthening of the global economic integration and regional economic groupings, which make the country risk become an important factor to consider in the financial institutions following the credit risk exposure. In the field of international loan and financing, the national risk is in default of the debt countries, and the government of the debtor countries requires to re arrange the debt and so on. For example, in 1982 due to the Mexico, Brazil and other countries of the government of the re arrangement of the 10 largest U.S. central bank, the total risk exposure is $\$ 56000000$. In October 6, 1998, China's second largest trust investment company, Guangdong international Trust Investment Company (GITIC), was ordered to shut down by the Chinese people's Bank, and the Chinese government made it clear that it would not pay for a debt if it was not guaranteed by governments at all levels. GITIC bankruptcy caused a great reaction at home and abroad, people worry that closed GITIC will shake the foreign banks and investors to China's credit, even of China's solvency in doubt. This shows that our country's risk has become one of the important factors that the government and the financial institutions to consider in the future (see figure 1). Therefore, the financial institutions in the country live in foreign loans to borrowers in addition to assess the quality of the borrower's basic credit risk, but also to assess the country's home country risk quality, and national risk assessment is more important than the enterprise credit risk assessment. Now, the national risk of financial rating agencies have become a super power in the field of international finance, some public opinion are even called "the 
financial police". Because its assessment results will directly affect the confidence of the community to be assessed, and promote the interest rate of the loan by the lift, the impact of financial security is evaluated.

Here, with these matters and the fast-speed development of China's financial system, the world needs a more stable China's financial system. Financial institutions are the basis. Therefore, the paper aims to discuss the methods used to evaluate operational risk in the west countries and put forward two measures to deal with such financial risks.

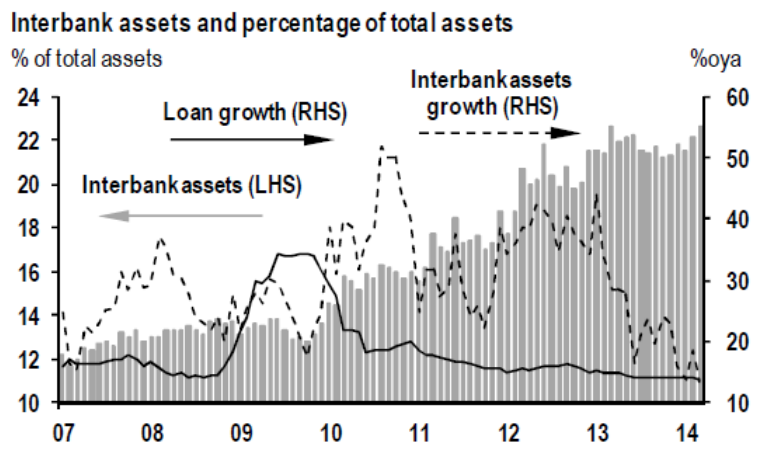

Figure 1. The china's report of risk assessment

\section{Current International Risk Assessment Index System of the Country}

At present, the quantitative problem of national risk assessment is the problem of interest in the financial institutions, enterprises and academic institutions. In order to make the national risk assessment operational, many international organizations have their own assessment of the national risk of an indicator system. Summed up with the following:

1) The national risk assessment index system of the famous financial publications, mainly in the "European currency" magazine of the European currency risk level indicators and institutional investors, institutional investors in the investment risk level indicators.

2) National risk rating indicators for different research institutions in various countries including the national risk level of the Japan Inc., the national risk warning system developed by the German Economic Research Institute and the national risk international guide (ICRG) prepared by the United States New York international report group. The national risk rating of the Institute of Japan Inc. bonds includes 14 projects. Respectively: The effectiveness of the continuity of the danger of civil war, riots and revolution; political stability; policy; the mature of the industrial structure; economic activities interference; fiscal policy; monetary policy effectiveness. The potential of economic development; the danger of war; the position of international reputation; the structure of the balance of payments; the ability to pay; foreign policy; exchange rate policy. National risk early warning system developed by the German economic research institute. The system includes a series of economic indicators, which are used to examine the state of a country's national risk, in order to draw the attention of the country before the country's national risk. The early warning system includes the following indicators and ratios: Ratio of the ratio of debt to debt, the ratio of the principal, the ratio of the debt to the ratio of the amount of debt to the gross national product and the ratio of the amount of the debt to the export. The ratio of liabilities to foreign exchange reserves, current ratio, current account deficit to the rate of export, and the growth rate of money supply. The ratio of fiscal deficit to GDP and the ratio of loan to IMF funds to the organization in the country. National risk international guide (ICRG) for the preparation of the New York international report group. ICRG's Composite Index (CPFER) is divided into three parts: political, financial and economic, and the political factor (PF) analysis of 100 points, the proportion is $50 \%$; the financial factor $(\mathrm{FF})$ is 50 , the proportion is $25 \%$; the economic factor $(\mathrm{EF})$ is 50 , the proportion is $25 \%$.

3) International Financial Rating agency. These ratings agencies are increasingly specialized and systematic, and more and more international business activities are to be referred to their rating results. According to market needs, the company's rating range continues to expand. Rating firm also for the development trend of debt credit, established the observation, positive, negative and other assessment system. To Moodier, for example, its influence has penetrated into all aspects of the world economy, contributed to the further deepening of the financial crisis, but also seriously undermined the stability of the Southeast Asian system. But it cannot be ignored in the crisis in some of the unique role, it's some of the assessment of the economic law of the composition, and the function of 
compulsory correction. Most of its conclusions are conducive to avoid further credit crisis, to ensure that the interests of the borrower, but also to help the country and the economy to address the problem, accelerate financial reform.

\section{Model of Risk Assessment of Financial Institutions}

\subsection{The Basic Idea of Establishing the Risk Assessment Model of Financial Institution}

1) Comply with the internal and external situation of financial institutions (see Figure 2). Financial institutions credit risk management work, in order to financial institutions internal planning and external market conditions for the fundamental, in particular, the competition between financial institutions to rationalize, in accordance with the financial institutions of the "profit" and "risk return" as the guide. And it is a combination of the new Basel agreement internal credit risk scale standards, in order to build a credit risk assessment model, it is able to adapt to the internal planning and external competition of financial institutions. Financial institutions in the construction of credit risk assessment model is not just to assess the credit risks of financial institutions a business. Instead, it is based in domestic and international financial markets, considering financial institutions internal business in financial market positioning, in order to make the risk assessment results fit the internal and external environment of financial institutions.

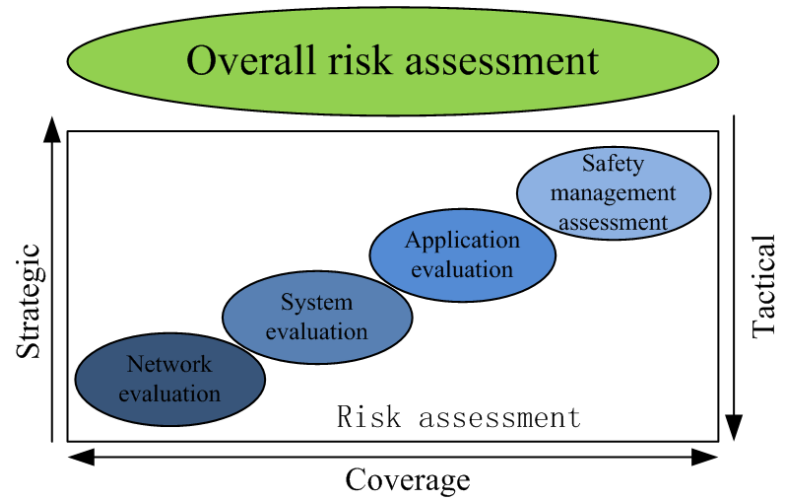

Figure 2. Risk assessment of basic model for financial institutions

2) Compliance risk management needs. Financial institutions in credit risk evaluation model construction, must adapt to the full range of risk management demand, the introduction of the risk factors of qualitative analysis and quantitative calculation, more accurate determination of the borrowers default probability, and calculated default losses accumulated, thus for the scientific decision-making of loan with a strong support, credit risk assessment of financial institutions has the characteristics of complexity, the borrower failed to analyze the financial situation of the borrower before the loan, and set the financial indicators of the loan business, it is unable to factor analysis of the sample, and the timely loan will have a greater risk. The financial institution credit risk assessment model, which can meet the needs of the full range of risk management, set up a linear function between the level of the loan and the financial indicators, and calculate the financial indicators of the enterprise to estimate the credit risk level of the enterprise.

3) Stability of guarantee model prediction. The credit risk of financial institutions is generally divided into two levels, normal and default, that is, the normal loan and loan default, while the sample size is small, the total sample size is estimated to be 150 or so. In view of this situation, the credit risk assessment model of financial institutions, we must overcome this capacity defect, with independent multivariate statistical techniques, the formation of multiple levels of mathematical model. Such credit risk assessment, we can select more financial indicators as analysis variables, the original risk level, expand normal borrowing, overdue loans, overdue interest loans, stagnant loans, non-performing loans in the field.

\subsection{Establishment Method of Risk Assessment Model of Financial Institution}

1) Select sample data and indicators

Analysis of credit assessment data of financial institutions, the basis is to ensure the validity of the data, and financial institutions credit risk assessment of the relevant data, from the form of loans, which relates to the loan companies in the industry market, and the business scale, etc. Here, a financial institutions a total of 420 loan as the sample data 
and according to the common status of loans, these loans classified as normal loans, overdue loans, overdue interest loans, stagnant loans and bad loans five types, Which 200 as the estimation samples, 220 pen in order to test the model, while the estimated sample is divided into 63 normal loans, 34 overdue loans, 24 owed for loans, 19 bad loans, 60 idle loans. The initial index set of credit risk assessment model is formed after the classification of good credit.

2) Building risk assessment model

The first is the analysis of the factors, which can represent the comprehensive index of various types of information, and determine the original variables and the main components. Then, in the form of matrix, the relationship between the various factors and the original variables is expressed. After analysis, it can be seen that the size of the original variable vector, which is related to the factor load factor matrix, the factor vector and the residual vector. Finally, by comparing the simple correlation coefficient between the observed variables, the variables that are not suitable to be analyzed. Followed by stepwise discriminant model, model checking discriminant force with the biggest variable and removed from the model mismatch variables, synchronization using stepwise discriminant analysis method, forming criterion statistics, draws the inventory turnover rate, liquidity ratio, debt receivable turnover, sales margin, ratio of fixed assets, main business profit rate, total asset turnover ratio etc. In order to determine the normal borrowing, overdue loans, overdue interest loans, stagnant loans, non-performing loans function, through stepwise discriminant and predictive classification, you can compare error judgment rate.

3) Test risk assessment model

The test of the financial institutions in credit risk assessment model, on the one hand, is testing the linear discriminant model, according to determine the discriminant function, to focus on examination of the test sample, substitution of each discriminant function, the size of the value function to determine belongs to the category of the sample. According to the judgment, linear discriminant model to test samples of the overall discriminant accuracy rate reached $64 \%$, especially for normal loans, overdue loans and interest owed loans. The classification accuracy rate was the highest, and for other types of loans, the prediction accuracy is not high. The estimated in a sample of normal loan $68.1 \%$, overdue $83.3 \%$ of loans, loan interest owed $76.0 \%$, 37.5\% of doubtful loan, stagnant loans $51.5 \%$, test samples of normal loan $68.8 \%$, overdue $84.8 \%$ of loans, loan interest owed $76.0 \%, 16.7 \%$ of doubtful loan, stagnant loans 50.7\%; On the other hand, a logistic regression model was used in the test, and the test results indicated that all samples prediction accuracy rate of up to $68 \%$, especially in samples of normal loans and idle loans, where the prediction accurate rate is the highest. The estimation samples in normal $88.0 \%$ of loans, overdue loan $76.7 \%$, under interest free loan $86.0 \%, 22.5 \%$ of doubtful loan, stagnant loans $78.5 \%$, sample test $84.7 \%$ of normal loans, overdue loan $65.3 \%$, loan interest owed $36.3 \%, 36.7 \%$ of doubtful loan, stagnant loans $75.9 \%$; This shows that this type of risk assessment model is more suitable for the current assessment of the credit risk of financial institutions.

\subsection{The External Model of Risk Assessment of Financial Institutions}

First financial institutions should refer to the assessment value of the easy access to the external risk assessment agency. At present, the main reference of the financial institution is the evaluation of the two major financial publications. These two publications are the "INSTITUTIONAL" (MONEY EURO) national risk rating indicators and the "institutional investors" (INVESTOR) national risk rating index.

European Monetary index. The European monetary index is "the European currency" magazine invited 100 economists, politicians and bankers to give results about the global 133 countries and regions of the country's comprehensive analysis and assessment of risk. The index was originally published in 1979, when the European market was mainly targeted at the European market for the country's debt expectations of higher than the London interbank lending rates. And based on the spread of this market as the basis to determine the amount of debt issuance and maturity.

\subsection{Internal Model of Risk Assessment of Financial Institutions}

The internal model of the financial institution's national risk assessment is mainly to develop the statistical model. So far, the most popular method is the sovereign state risk score model, which is based on the key economic variables in each country. This is similar to the domestic credit risk $\mathrm{Z}$ score model, the main steps of the model used in national risk analysis are as follows:

1) Select key variables. When choosing a key variable, it is important to ask these variables to explain the probability of re arrangement. In most cases, the analyst has to choose suitable variables, here we have a choice from five kinds of variables that often include the risk probability model in the country. These five economic variables are: debt 
service ratio (DSR), import ratio (IR), investment ratio (INVR), export earnings variance (VAREX) and domestic money supply growth rate (MG). They can be used to express the relationship between the five economic variables and the re arrangement of probability $P$.

2) Multiple difference model. According to the expectation of the key economic variables and the re arrangement of the probability of $\mathrm{P}$, the model of the risk of any country can be established: $\mathrm{P}=\mathrm{f}$ (DSR, IR, INVR, VAREX, MG$--)$.

3) Determine the risk level. After selecting the key variables, the country can be divided into two groups: P1= difference (re arrangement), $\mathrm{P} 2$ = good (non-rearranged), and can be applied to identify the analysis model to identify which variable is the most able to identify the re arrangement and non re arrangement. Once the key variables and variables are identified, the identification model can be applied to the existing observations of the various key variables such as IR, DSR, etc., to distinguish between sovereign state loan and sovereign state loan applications.

\section{Risk Countermeasure of Financial Institution}

As the problem of financial institutions and financial risk has a strong negative externality and different disposal modes will directly affect the interests and resources allocation, the choice of risk management mode is a matter of great importance and has been highly controversial. In the financial crisis, the governments of the developed countries launched a greater strength of the biggest rescue operations for the problem of the financial institutions, including the use of large-scale state-owned institutions. But such a move would lead to the market's concerns about moral hazard, and a reflection on the existing financial regulatory system. In this regard, the academic community has been widely discussed, the main point of view, including two aspects: market and administrative intervention.

Research shows that through the market and the two ways can get the best way to deal with the effect. The smaller the proportion of a single entity in the process of risk management, it can achieve better disposal effect with the help of the market approach. And in extreme cases, even if the market mechanism is perfect, the market size is also great, but if the problem is huge. At this point, the effect of risk management through the way of marketing will be greatly reduced, and the larger scale of administrative intervention measures (such as government assistance) may be a better choice. In addition, we can get the optimal risk management mode for different stages of market development. For example, in the early stage of market development, the optimal risk management mode should be the administrative leading. While in the market development to a more mature stage, the majority of companies are unable to form a significant impact on the market conditions, the market led disposal mode will be optimal. And the intermediate transition between the combination of administrative and market risk management approaches is more ideal.

\section{Conclusion}

Through the above of financial institutions risk assessment index system and financial institutions from their own national risk assessment of the internal model and the external model review, this paper puts forward the method of building the risk assessment model for financial institutions. In order to make the risk assessment more objective and more accurate, the financial institution must be combined with the variable information, so as to make the risk assessment more objective and more accurate. Finally, the paper puts forward the strategies for financial institutions' risk coping strategies from two aspects of market oriented and government intervention.

\section{References}

Aniūnas, P., Nedzveckas, J., \& Krušinskas, R. (2015). Variance-covariance risk value model for currency market. Engineering Economics, 61(1).

Arinaminpathy, N., Kapadia, S., \& May, R. M. (2012). Size and complexity in model financial systems. Proceedings of the National Academy of Sciences, 109(45), 18338-18343. http://dx.doi.org/10.1073/pnas.1213767109

Arnold, B., Borio, C., Ellis, L., et al. (2012). Systemic risk, macroprudential policy frameworks, monitoring financial systems and the evolution of capital adequacy. Journal of Banking \& Finance, 36(12), 3125-3132. http://dx.doi.org/10.1016/j.jbankfin.2012.07.023

Bisias, D., Flood, M. D., Lo, A. W., et al. (2012). A survey of systemic risk analytics. US Department of Treasury, Office of Financial Research, (0001).

Blankespoor, E., Linsmeier, T. J., Petroni, K. R., et al. (2013). Fair value accounting for financial instruments: Does it improve the association between bank leverage and credit risk?. The Accounting Review, 88(4), 1143-1177. http://dx.doi.org/10.2308/accr-50419

Bonsón, E., \& Flores, F. (2011). Social media and corporate dialogue: the response of global financial institutions. 
Online Information Review, 35(1), 34-49. http://dx.doi.org/10.1108/14684521111113579

Brown, S., Goetzmann, W., Liang, B., et al. (2012). Trust and delegation. Journal of Financial Economics, 103(2), 221-234. http://dx.doi.org/10.1016/j.jfineco.2011.09.004

Chernobai, A., Jorion, P., \& Yu, F. (2012). The determinants of operational risk in US financial institutions. Journal of Financial and Quantitative Analysis, 46(6), 1683-1725. http://dx.doi.org/10.1017/S0022109011000500

Embrechts, P., Puccetti, G., Rüschendorf, L., et al. (2014). An academic response to Basel 3.5. Risks, 2(1), 25-48. http://dx.doi.org/10.3390/risks2010025

Huang, X., Zhou, H., \& Zhu, H. (2012). Assessing the systemic risk of a heterogeneous portfolio of banks during the recent financial crisis. Journal of Financial Stability, 8(3), 193-205. http://dx.doi.org/10.1016/j.jfs.2011.10.004

Le, L. V., \& Avramova, S. Y. (2012). Revisiting risk-weighted assets.

Michalski, G. (2012). Accounts receivable management in nonprofit organizations. Zeszyty Teoretyczne Rachunkowości, (68), 83-96. http://dx.doi.org/10.2139/ssrn.2193352

Mircea, M., \& Andreescu, A. I. (2011). Using cloud computing in higher education: A strategy to improve agility in the current financial crisis. Communications of the IBIMA, 2011, 1-15. http://dx.doi.org/10.5171/2011.875547

Xiaochuan, Z., \& Li, Z. (2014). China's Banking System: current status, perspective on reform. Chinese Economic Reform: How Far, How Fast?, 11, 109. 